\title{
Neutrophil Lymphocyte Ratio in Estimating Response to Corticosteroid Treatment in Immune Thrombocytopenia Patients
}

\author{
Nötrofil Lenfosit Oranı İmmün Trombositopeni Hastalarında Kortikosteroid \\ Tedavisine Yanıtı Öngörebilir mi?
}

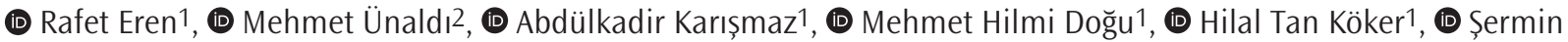 \\ Altındal1', (D) Osman Yokuş ${ }^{1}$, (D) Elif Suyanı
}

1 istanbul Training and Research Hospital, Clinic of Hematology, İstanbul, Turkey

2istanbul Training and Research Hospital, Clinic of Internal Medicine, İstanbul, Turkey

\begin{abstract}
Introduction: We aimed to investigate the association between neutrophil lymphocyte ratio (NLR) and response and loss of response to corticosteroid treatment in immune thrombocytopenia patients (ITP).

Methods: We retrospectively analyzed the data of 47 ITP patients treated with corticosteroid therapy at Istanbul Training and Research Hospital Clinic of Hematology between 2007 and 2016. NLR was calculated using complete blood count of patients at the time of diagnosis. The cut-off score for NLR was determined at 2.5 according to median NLR level.

Results: Twenty-three (48.9\%) patients had NLR $<2.5$ and $24(51.1 \%)$ patients had NLR $\geq 2.5$. There was no statistically significant relationship between NLR and treatment response, response duration and loss of response $(p=0.74, p=0.869$, $p=0.315$, respectively).

Conclusion: Although NLR was found to be associated with the prognosis and activity of various diseases in several studies, we could not verify such an association between NLR and response to corticosteroid therapy in ITP patients.
\end{abstract}

Keywords: Corticosteroid, immune thrombocytopenia patients, neutrophil lymphocyte ratio

\section{öz}

Amaç: Bu çalışmada immün trombositopeni (ITP) hastalarında nötrofil lenfosit oranı (NLO) ile kortikosteroid tedavisine yanıt ve yanıt kaybı arasındaki ilişkiyi araşıtırmayı amaçladık.

Yöntemler: 2007 ile 2016 yılları arasında İstanbul Eğitim ve Araștırma Hastanesi Hematoloji Kliniğinde kortikosteroid ile tedavi edilmiş 47 ITP hastasının verileri retrospektif olarak incelendi. NLO, hastaların tanı anındaki hemogramları kullanılarak hesaplandı. Medyan NLO düzeyine göre NLO için eșik değer 2,5 olarak belirlendi.

Bulgular: Yirmi üç hastada $(\% 48,9)$ NLO $<2,5$ ve 24 hastada $(\% 51,1)$ NLO $\geq 2,5$ idi. NLO ile tedavi yanıtı, yanıt süresi ve yanıt kaybı arasında istatistiksel anlamlı ilişki yoktu $(p=0,74$; $p=0,869 ; p=0,315)$.

Sonuç: NLO birçok çalışmada çeşitli hastalıkların prognozu ve aktivitesi ile iliş̧kili bulunmuştur. Çalışmamızda ise NLO ile ITP hastalarında kortikosteroid tedavisine yanıt arasındaki ilișki doğrulanamamıştır.

Anahtar Kelimeler: Kortikosteroid, immün trombositopeni, nötrofil lenfosit oranı

\section{Introduction}

Immune thrombocytopenia (ITP) is an acquired autoimmune disease characterized by isolated thrombocytopenia which is attributed to enhanced destruction and impaired production of platelets, often without a definable specific stimulus (1-3). Despite the implementation of novel agents such as thrombopoietin receptor agonists, corticosteroids (CSS) are still the first line recommended therapy for ITP patients who need treatment $(1,3,4)$. Initial response rate to CS treatment is promising, varying from 50 to $90 \%$; however, durable platelet response could be maintained in only $10-30 \%$ of patients, when the CS treatment is tapered off or ceased (5).

Inflammation is known to have a significant role in the course of many benign (6) and malignant diseases (7). Neutrophil lymphocyte ratio (NLR), being an inexpensive and easily available parameter, has been used frequently as a marker of systemic inflammation in recent years (6). The association between elevated NLR and the disease course, prognosis and treatment response has been established in several benign (8-14) and malignant $(15,16)$ diseases.
Address for Correspondence/Yazıșma Adresi: Rafet Eren, İstanbul Training and Research Hospital, Clinic of Hematology, İstanbul, Turkey

Phone: +90 5319961842 E-mail: drrafeteren@gmail.com ORCID ID: orcid.org/0000-0003-0973-6279

Cite this article as/Atıf: Eren R, Ünaldı M, Karışmaz A, Doğu MH, Tan Köker H, Altındal Ș, Yokuş O, Suyanı E. Neutrophil Lymphocyte Ratio in Estimating Response to Corticosteroid Treatment in Immune Thrombocytopenia Patients. İstanbul Med J 2019; 20(1): 54-7.
Received/Geliș Tarihi: 29.03.2018 Accepted/Kabul Tarihi: 23.05.2018

(c) Copyright 2019 by the Istanbul Training and Research Hospital/istanbul Medical Journal published by Galenos Publishing House.

(C) Telif Hakkı 2019 Istanbul Ĕgitim ve Araștırma Hastanesi/Istanbul Tıp Dergisi, Galenos Yayınevi tarafından basılmıștır. 
Even though ITP is an autoimmune disease, the data regarding the relationship between ITP and inflammatory markers is not sufficient. Also, there is limited data with respect to the factors affecting response to CS treatment (17-19). So, we aimed to investigate the association between NLR and response, and loss of response to CS treatment in ITP patients who needed treatment.

\section{Methods}

We retrospectively analyzed the data of 47 ITP patients treated with CS therapy at Istanbul Training and Research Hospital, Clinic of Hematology between 2007 and 2016. The data including age, gender, bleeding history, complete blood count at the time of diagnosis, NLR at the time of diagnosis, treatment response, loss of response, and duration of response were recorded for each patient. ITP diagnosis and treatment demand were defined according to The American Society of Hematology practice guidelines (1). We started treatment for patients with platelet count below $30 \times 10^{9} / \mathrm{L}$ or patients with bleeding. Response to treatment was assessed according to the recommendations of the international working group (20). Response was defined as a platelet count greater than $30 \times 10^{9} / \mathrm{L}$ and no response was defined as a platelet count less than $30 \times 10^{9} / \mathrm{L}$, while loss of response (LOR) was defined as a platelet count less than $30 \times 10^{9} / \mathrm{L}$ or a less than 2 -fold increase in the platelet count from baseline or the presence of bleeding. We did not further evaluate the patients according to complete remission, since the cohort was not large enough for such a detailed analysis. Forty-five patients received methylprednisolone and 2 patients received dexamethasone treatment as first line therapy. NLR was calculated using complete blood count of patients at the time of diagnosis. The cut-off score for NLR was determined at 2.5 according to median NLR level.

The study protocol has been approved by the Istanbul Training and Research Hospital Ethics Committee (date: 06.01.2017 no: 924) and written informed consent was obtained from all patients.

\section{Statistical Analysis}

Statistical analysis was performed using SPSS version 24 (IBM Corp., Armonk, NY, USA) software. Data were described as numbers and percentage or median and range, where appropriate. Chi-square test or Fisher's exact test was used for evaluating categorical values and MannWhitney $U$ test for continuous values in patient groups. Spearman test was used for correlation analysis. A $p$ value of $<0.05$ was considered statistically significant.

\section{Results}

Patient characteristics are summarized in Table 1. The median age of the patients at the time of diagnosis was 44 years (range, 18-74). Twenty-seven (57\%) patients were female and 20 (43\%) were male. Ten (21.3\%) patients had a history of bleeding at the time of diagnosis. The median white blood cell count was $7,850 / \mathrm{mm}^{3}\left(4.710-21.090 / \mathrm{mm}^{3}\right)$, hemoglobin level was $13.2 \mathrm{~g} / \mathrm{dL}(8.3-17.80 \mathrm{~g} / \mathrm{dL})$, platelet count was $9.000 / \mathrm{mm}^{3}\left(0-37.000 / \mathrm{mm}^{3}\right)$, neutrophil count was $5.200 / \mathrm{mm}^{3}(2.210$ $\left.16.900 / \mathrm{mm}^{3}\right)$, and lymphocyte count was $1.970 / \mathrm{mm}^{3}\left(610-5.430 / \mathrm{mm}^{3}\right)$. Thirty-five (74.5\%) patients responded to first line treatment, however, LOR developed in 19 (54.2\%) of these patients during follow-up. The median NLR was 2.51 (range, 1.15-11.35), and the cut-off for NLR was assigned as 2.5 according to the median NLR level. Twenty-three (48.9\%) patients had NLR $<2.5$ and 24 (51.1\%) patients had NLR $\geq 2.5$. There was no statistical significant difference between two groups regarding age, gender, treatment response, response duration and $\operatorname{LOR}(p=1, p=0.92$, $p=0.74, p=0.869, p=0.315$ ) (Table 2). Also there was no correlation between NLR and response duration $(p=0.918, r=0.018)$.

\section{Table 1. Patient characteristics}

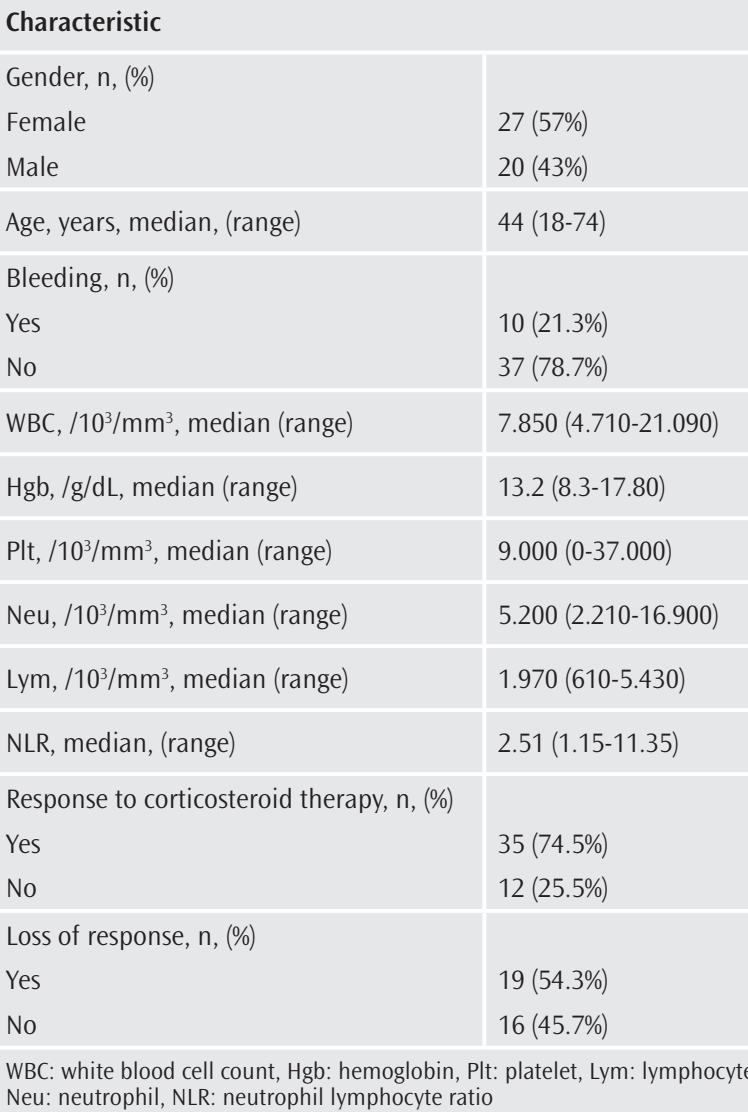

Neu: neutrophil, NLR: neutrophil lymphocyte ratio

Table 2. Comparison of patients with neutrophil lymphocyte ratio $<2.5$ and neutrophil lymphocyte ratio $\geq 2.5$

\begin{tabular}{|c|c|c|c|}
\hline & $\begin{array}{l}\text { NLR }<2.5 \\
n=23\end{array}$ & $\begin{array}{l}N L R \geq 2.5 \\
n=24\end{array}$ & $\mathbf{p}$ \\
\hline \multicolumn{4}{|l|}{ Gender, n, (\%) } \\
\hline Female & $13(57 \%)$ & $14(58 \%)$ & \multirow{2}{*}{1} \\
\hline Male & $10(43 \%)$ & $10(42 \%)$ & \\
\hline Age, years, median, (range) & $44(18-73)$ & $44(26-74)$ & 0.92 \\
\hline \multicolumn{4}{|l|}{$\begin{array}{l}\text { Response to corticosteroid } \\
\text { therapy, } n,(\%)\end{array}$} \\
\hline Yes & $18(78.3 \%)$ & $17(70.8 \%)$ & \multirow{2}{*}{0.740} \\
\hline No & $5(21.7 \%)$ & $7(29.2 \%)$ & \\
\hline $\begin{array}{l}\text { Response duration to } \\
\text { corticosteroids, months, } \\
\text { median, (range) }\end{array}$ & $8.5(1-60)$ & $7(1-105)$ & 0.869 \\
\hline \multicolumn{4}{|l|}{ Loss of response, $n,(\%)$} \\
\hline Yes & $8(44.4 \%)$ & $11(64.7 \%)$ & \multirow{2}{*}{0.315} \\
\hline No & $10(55.6 \%)$ & $6(35.3 \%)$ & \\
\hline
\end{tabular}




\section{Discussion}

While impaired platelet production plays a role in the pathogenesis of ITP, the fundamental step in occurrence of the disease is the production of abnormal autoantibodies specific to platelet membrane antigens. Subsequently, those antibodies bind to the membranes of circulating platelets $(2,3,21)$. Autoantibody-bound platelets induce Fc receptormediated phagocytosis by macrophages primarily in spleen, leading to increased destruction of platelets $(2,3,21)$. The triggering event in the development of antibody production remains unclear; however direct interaction of monocyte subgroups with $\mathrm{T}$ helper/T regulatory lymphocytes has been implicated in eliciting the events $(22,23)$. This autoimmune nature of the disease makes CSs as the first-line therapy, which acts through decreasing the production of autoantibodies and suppressing the reticuloendothelial phagocytosis of antibody-coated platelets in ITP $(2,24)$. Of note that, the response rate particularly sustained platelet response to CSs is not excellent different than anticipated (2,5). Nowadays, identifying risk factors has become important for tailoring individualized treatments in the majority of the diseases. Several factors such as age (17), gender (17), platelet count at diagnosis (17), abnormal platelet morphology (18) were investigated whether they affected response to corticosteroid treatment or not in ITP patients. Among them, abnormal platelet morphology was found to be associated with poor response to CS therapy. Although the data about the factors affecting the response to CS treatment is not obvious, infectious agents like H. pylori, human immunodeficiency virus, hepatitis $\mathrm{C}$ virus, cytomegalovirus (CMV), have been reported to augment thrombocytopenia in refractory ITP patients (3). In our study, we evaluated the association of NLR with response to CS treatment in ITP patients and we did not find an association. While 35 (74.5\%) patients responded to first line treatment, LOR developed in 19 (54.2\%) of these patients during follow-up.

The association of elevated NLR with advanced disease and prognosis has been elucidated quite well in various malignancies $(15,16)$. In addition, NLR has been elevated in autoimmune diseases like systemic lupus erythematosus (SLE) $(9,25,26)$, rheumatoid arthritis (RA) (10), Sjögren's syndrome (27), and autoimmune thyroiditis $(28,29)$. Also, increased NLR was shown to be an indicator of disease activity in $\operatorname{SLE}(26), \operatorname{RA}(10,30)$, and Sjögren syndrome (27). On the contrary, the data concerning the role of NLR in some other autoimmune diseases such as Behçet's disease $(11,12)$ and psoriasis $(13,14)$ is conflicting. According to our knowledge, the role of NLR in adult ITP patients has not been explored previously. On the other hand, the association of low lymphocyte and leukocyte count with disease course in pediatric ITP patients were studied in two studies $(31,32)$. Ahmed et al. (31) showed that low leukocyte and lymphocyte count at the time of diagnosis was a predictive parameter for persistence in pediatric ITP patients. Nevertheless, the treatment details of the patients were not noted in the study. Similarly, Deel et al. (32) found that low lymphocyte count at $3^{\text {rd }}$ month was correlated with progression to chronic ITP. Also, majority of the patients were not treated with steroids in that study. In the current study, when we compared ITP patients who responded to first-line therapy with non-responders, we did not find a significant difference in NLR values between two groups.

Accordingly, several issues can be proposed to explain the insignificant results in our study. First, we did not have adequate data concerning the infection history of the patients, particularly H. pylori and CMV infection, which might have played a role in refractoriness. Secondly, subsets of lymphocytes asserted to have role in the pathogenesis of the disease constitutes only minority of the lymphocytes (33), thus any structural or quantitative abnormality in these cells would not allow alteration in lymphocyte count and also NLR. Unfortunately, we could not evaluate these factors due to the retrospective nature of the study. Lastly and the most important one according to us is that, ITP is not a systemic disease affecting the other organs leading to systemic inflammation.

\section{Conclusion}

In conclusion, although NLR was found to be associated with the prognosis and activity of various diseases in several studies, we could not verify such an association between NLR and response to corticosteroid therapy in ITP patients.

Ethics Committee Approval: The study protocol has been approved by the Istanbul Training and Research Hospital Ethics Committee (date: 06.01.2017 no: 924).

Informed Consent: Written informed consent was obtained from all patients.

\section{Peer-review: Externally peer-reviewed.}

Author Contributions: Concept - R.E., E.S., O.Y.; Design - M.H.D., H.T.K.; Supervision - M.H.D., S.A.; Resources - R.E., M.Ü., A.K.; Materials - M.Ü., H.T.K., A.K.; Data Collection and/or Processing - R.E., A.K.; Analysis and/ or Interpretation - S.A., O.Y., E.S.; Literature Search - R.E., M.Ü., H.T.K.; Writing Manuscript - R.E., E.S.; Critical Review - M.H.D., S.A., O.Y., E.S

Conflict of Interest: No conflict of interest was declared by the authors.

Financial Disclosure: The authors declared that this study received no financial support.

\section{References}

1. Neunert C, Lim W, Crowther M, Cohen A, Solberg L Jr, Crowther MA; American Society of Hematology. American Society of Hematology. The American Society of Hematology 2011 evidence-based practice guideline for immune thrombocytopenia. Blood 2011; 117: 4190-207.

2. Stasi R, Evangelista ML, Stipa E, Buccisano F, Venditti A, Amadori S. Idiopathic thrombocytopenic purpura: current concepts in pathophysiology and management. Thromb Haemost 2008; 99: 4-13.

3. Psaila B, Bussel JB. Refractory immune thrombocytopenic purpura: current strategies for investigation and management. Br J Haematol 2008; 143: 16-26.

4. Cuker A, Neunert CE. How I treat refractory immune thrombocytopenia. Blood 2016; 128: 1547-54.

5. Cines DB, Bussel JB. How I treat idiopathic thrombocytopenic purpura (ITP). Blood 2005; 106: 2244-51.

6. Imtiaz F, Shafique K, Mirza SS, Ayoob Z, Vart P, Rao S. Neutrophil lymphocyte ratio as a measure of systemic inflammation in prevalent chronic diseases in Asian population. Int Arch Med 2012; 5: 2.

7. Lu H, Ouyang W, Huang C. Inflammation, a key event in cancer development. Mol Cancer Res 2006; 4: 221-33.

8. Bhat T, Teli S, Rijal J, Bhat H, Raza M, Khoueiry G, et al. Neutrophil to lymphocyte ratio and cardiovascular diseases: a review. Expert Rev Cardiovasc Ther 2013; 11: 55-9. 
9. Li L, Xia Y, Chen C, Cheng P, Peng C. Neutrophil-lymphocyte ratio in systemic lupus erythematosus disease: a retrospective study. Int J Clin Exp Med 2015; 8: $11026-31$

10. Uslu AU, Küçük A, Şahin A, Ugan Y, Yılmaz R, Güngör T, et al. Two new inflammatory markers associated with Disease Activity Score-28 in patients with rheumatoid arthritis: neutrophil-lymphocyte ratio and plateletlymphocyte ratio. Int J Rheum Dis 2015; 18: 731-5.

11. Rifaioglu EN, Bülbül Şen B, Ekiz Ö, Cigdem Dogramaci A. Neutrophil to lymphocyte ratio in Behçet's disease as a marker of disease activity. Acta Dermatovenerol Alp Pannonica Adriat 2014; 23: 65-7.

12. Alan S, Tuna S, Türkoğlu EB. The relation of neutrophil-to-lymphocyte ratio, platelet-to-lymphocyte ratio, and mean platelet volume with the presence and severity of Behçet's syndrome. Kaohsiung J Med Sci 2015; 31: 626-31.

13. Kim DS, Shin D, Lee MS, Kim HJ, Kim DY, Kim SM, et al. Assessments of neutrophil to lymphocyte ratio and platelet to lymphocyte ratio in Korean patients with psoriasis vulgaris and psoriatic arthritis. J Dermatol 2016; 43: 305-10.

14. Ataseven A, Bilgin AU, Kurtipek GS. The importance of neutrophil lymphocyte ratio in patients with psoriasis. Mater Sociomed 2014; 26: 231-3.

15. Templeton AJ, McNamara MG, Seruga B, Vera-Badillo FE, Aneja P, Ocana A, et al. Prognostic role of neutrophil-to-lymphocyte ratio in solid tumors: a systematic review and meta-analysis. J Natl Cancer Inst 2014; 106: dju124.

16. Guthrie GJ, Charles KA, Roxburgh CS, Horgan PG, McMillan DC, Clarke SJ. The systemic inflammation-based neuthrophil lymphocyte ratio: experience in patients with cancer. Crit Rev Oncol Hematol 2013; 88: 218-30.

17. Syed NN, Adil SN, Sajid R, Usman M, Moiz B, Kakepoto GN, et al. Chronic ITP: analysis of various factors at presentation which predict failure to first line treatment and their response to second line therapy. J Pak Med Assoc 2007; 57: 126-9.

18. Tripathi AK, Mishra S, Kumar A, Yadav D, Shukla A, Yadav Y. Megakaryocyte morphology and its impact in predicting response to steroid in immune thrombocytopenia. Platelets 2014; 25: 526-31.

19. Basciano PA, Bussel J, Hafeez Z, Christos PJ, Giannakakou P. The beta 1 tubulin $\mathrm{R} 307 \mathrm{H}$ single nucleotide polymorphism is associated with treatment failures in immune thrombocytopenia (ITP). Br J Haematol 2013; 160: 237-43.

20. Rodeghiero F, Stasi R, Gernsheimer T, Michel M, Provan D, Arnold DM, et al. Standardization of terminology, definitions and outcome criteria in immune thrombocytopenic purpura of adults and children: report from an international working group. Blood 2009; 113: 2386-93.

21. Crow AR, Lazarus AH. Role of Fcgamma receptors in the pathogenesis and treatment of idiopathic thrombocytopenic purpura. J Pediatr Hematol Oncol 2003; 25 (Suppl 1): S14-8.
22. Zhong H, Bao W, Li X, Miller A, Seery C, Haq N, et al. CD16+ monocytes control T-cell subset development in immune thrombocytopenia. Blood 2012; 120 : 3326-35.

23. Yazdanbakhsh $\mathrm{K}$, Zhong $\mathrm{H}$, Bao W. Immune dysregulation in immune thrombocytopenia. Semin Hematol 2013; 50 (Suppl 1): S63-7.

24. Mizutani H, Furubayashi T, Imai $\mathrm{Y}$, Kashiwagi $\mathrm{H}$, Honda $\mathrm{S}$, Take $\mathrm{H}$, et al Mechanisms of corticosteroid action in immune thrombocytopenic purpura (ITP): experimental studies using ITP-prone mice, (NZW x BXSB) F1. Blood 1992; 79: 942-7.

25. Oehadian A, Suryadinata H, Dewi S, Pramudyo R, Alisjahbana B. The role of neutrophyl lymphocyte count ratio as an inflammatory marker in systemic lupus erythematosus. Acta Med Indones 2013; 45: 170-4.

26. Qin B, Ma N, Tang Q, Wei T, Yang M, Fu H, et al. Neutrophil to lymphocyte ratio (NLR) and platelet to lymphocyte ratio (PLR) were useful markers in assessment of inflammatory response and disease activity in SLE patients. Mod Rheumatol 2016; 26: 372-6.

27. Hu ZD, Sun Y, Guo J, Huang YL, Qin BD, Gao Q, et al. Red blood cell distribution width and neutrophil/lymphocyte ratio are positively correlated with disease activity in primary Sjögren's syndrome. Clin Biochem 2014; 47: 287-90.

28. Keskin H, Kaya Y, Cadirci K, Kucur C, Ziypak E, Simsek E, et al. Elevated neutrophil-lymphocyte ratio in patients with euthyroid chronic autoimmune thyreotidis. Endocr Regul 2016; 50: 148-53.

29. Arpaci D, Gurol G, Ergenc H, Yazar H, Tocoglu AG, Ciftci IH, et al. A Controversial New Approach to Address Hematological Parameters in Hashimoto's Thyroiditis. Clin Lab 2016; 62: 1225-31.

30. Fu H, Qin B, Hu Z, Ma N, Yang M, Wei T, et al. Neutrophil- and platelet-tolymphocyte ratios are correlated with disease activity in rheumatoid arthritis. Clin Lab 2015; 61: 269-73.

31. Ahmed I, Rajpurkar M, Thomas R, Chitlur M. Initial lymphocyte count and the development of persistent/chronic immune thrombocytopenic purpura. Pediatr Blood Cancer 2010; 55: 508-11.

32. Deel MD, Kong M, Cross KP, Bertolone SJ. Absolute lymphocyte counts as prognostic indicators for immune thrombocytopenia outcomes in children. Pediatr Blood Cancer 2013; 60: 1967-74.

33. Dieckmann D, Plottner H, Berchtold S, Berger T, Schuler G. Ex vivo isolation and characterization of $\mathrm{CD} 4(+) \mathrm{CD} 25(+) \mathrm{T}$ cells with regulatory properties from human blood. J Exp Med 2001; 193: 1303-10. 